\title{
Chromogranin Positive
}

National Cancer Institute

\section{Source}

National Cancer Institute. Chromogranin Positive. NCI Thesaurus. Code C147079.

An indication that expression of one or more chromogranin family proteins has been detected in a sample. 